九州大学学術情報リポジトリ

Kyushu University Institutional Repository

\title{
Agricultural Land Price and Agricultural Technological Progress
}

Tsuchiya, Ke izo

Laboratory of Quantitative Analysis of Agricultural Economics, Faculty of Agriculture, Kyushu University

https://doi.org/10.5109/22847

出版情報 : 九州大学大学院農学研究院紀要. 18 (1)，pp.69-80，1973-12. Kyushu University バージョン：

権利関係 : 


\title{
Agricultural Land Price and Agricultural Technological Progress
}

\author{
Keizo Tsuchiya \\ Laboratory of Quantitative Analysis of Agricultural Economics, \\ Faculty of Agriculture, Kyushu University, Fukuoka
}

(Received October 11, 1973)

\begin{abstract}
This paper includes the concepts of land rent from the standpoint of modern economics and accounts for the contributing factors in the formation of the agricultural land price during the prewar and the post-war periods. It can be said the agricultural land price in the later Taisho period was conditioned by farm rent and as far as the pure farming region is concerned, the agricultural land price in the post-war period is also explained considerably by net returns per 10 ares of land, which is capitalized by an 8 percent interest rate. Furthermore, the increase in agricultural land price, based on the premises of constant return to scale and the supported price of farm products, has demonstrated that the rise in the agricultural land price is sufficiently explained by technological progress in rice production.

Though various factors are considered important in the contribution to the formation of the agricultural land price in this paper the main emphasis is based upon the fact that the interior factors of agriculture considerably elucidate its formation throughout the prewar and the post-war period. This is especially applicable to the agricultural land price in pure farming regions.
\end{abstract}

\section{LAND RENT}

In agriculture, land is the most important production factor. There are different viewpoints among Marxian, classical, and modern economists. Among Marxian economics and classical economics, land rent is considered to be derived from surplus, whereas the generally accepted idea among modern economists is that it is determined by marginal productivity of land. However, modern economists do not necessarily have a unified viewpoint on land rent. It is true that certain famous modern economists maintain that the essence of land rent is surplus. For example, Marshall (1922) is one among them. According to his opinion that the essence of land rent was surplus and he introduced the concept of quasi-rent which could be extensively applied to fixed capital exclusive of land. Likewise, Robinson (1964) asserted that the essence of the concept of land rent was surplus. Consequently surplus had to exceed the minimum income which was necessary for the operation of production factors and was obtained by a particular part of the production factors.

However, these two different views on land rent among modern economists do not necessarily differ from each other completely, since the marginal productivity of land and surplus will be, in essence, equal as long as land is looked 
upon as a variable. For example, Wickstead (1894) demonstrated that what had been defined as surplus by the former economists was, in reality, equal to the marginal productivity of land under a certain distinctive condition. The representative view was provided by Wickstead (Stigler, 1968).

According to Wickstead, when the production function takes on a linear homogeneous expression with "constant returns to scale", the function containing three inputs of land $(\mathrm{X}$,$) , labor \left(X_{2}\right)$, capital $\left(X_{3}\right)$ and the total output $(Y)$ is defined by the formula:

$$
Y=f\left(X_{1}, X_{2}, X_{3}\right)
$$

(this is valid even if the variables increase, but for simplicity, we have employed only three variables for consideration).

According to the Euler's theorem, Equation (1) can be rewritten as follows:

$$
Y=\frac{\partial Y}{\partial X_{1}} X_{1}+\frac{\partial Y}{\partial X_{2}} X_{2}+\frac{\partial Y}{\partial X_{3}} X_{3}
$$

The marginal productivity of the production factors of land, labor and capital are consistent with land rent $(r)$, wage rate (w), and capital cost (k), respectively under perfect competition in both product market and production factors market. The following formula explains this algebraically :

$$
\mathrm{Y}=r X_{1}+w X_{2}+k X_{3}
$$

As a result, surplus $(R)$ obtained by subtracting wage and capital cost from the total output is simply as follows:

$$
R=Y-w X_{2}-k X_{3}=r X_{1}
$$

That is reverting back to land, $\frac{\partial Y}{\partial X_{1}} X_{1}=r X_{1}$ which must be distributed to land in accordance with the marginal productivity of land, $\frac{\partial Y}{\partial X_{1}}$, will be equal to surplus $(R)$. Thus, Wickstead contended that sub-pus is, in fact, a reversion consistent with the marginal value product of land and that the output will be completely distributed to every factor of production (This is called the "theory of exhaustion of product.").

Wickstead denied land rent as unearned income. He maintained that land and capital were, in an economic sense, identical and that land rent was to be imposed on capital, not on the original indivisible feature of land.

This view of capital and land is similar to prevalent ideas among modern economists. Ohkawa (1956), for example, explained land as "capital equipment with a special character."

Ricardo (1927) had made statements which have become more famous than he expected ; that land is "the original force of soil which will never destroyed." On the other hand, Hicks (1954), not attaching importance to this distinction but in reference to the similarity between land and fixed capital, stated, "Among durable goods there are some which naturally decrease after being used, land is one among them which is classified earlier. Most of the naturally decreasing 
goods are fixed capital. Here we must be careful not to put too much emphasis on the distinction between land and fixed capital."

Schultz's suggestion was similar to that of Hicks'. Schultz (1967) explained what led by Harrod (1951) to think that it would be appropriate to disregard land. Ricardo, in assigning the important role to agricultural land, reflected the circumstances of the time. He was quite right in so doing in the sense that in England the major portion of the household income was spent on food at that time. It was not until 1948 that Harrod came to observe in "Towards Dynamic Economics" that it would be appropriate to exclude land in selecting economic variables. Ricardo focused his attention on the problem concerning how every additional output produced from land would be distributed to each production factor at the various stages of economic growth. Harrod attempted to elucidate the occurrence of a depression in a developed country such as U. S. A. Among the circumstances of the times, the prevailing concepts of the economic position of land are reflected in both of their views. In some countries, it is clear that land has ceased to be a limiting factor. For example, economies in certain societies which enjoy highly advanced technology such as England, U. S. A. and others, have been free from severe constraints once imposed upon the economy by land.

Table 1 confirms the study put forward by Schultz (1960). In U. S. A. the ratios of agricultural income and land rent to national income were $17.8 \%$ and $3.2 \%$, respectively, during the years 1910-1914, but that they dropped to $5.7 \%$ and $0.6 \%$, respectively, during the years 1955-1957.

\begin{tabular}{cccc} 
Table 1. Ratio of land rent to national income & (U.S.A.)*. (unit $: \$ 100$ million) \\
\hline Years & $\begin{array}{c}\text { National } \\
\text { income }\end{array}$ & $\begin{array}{c}\text { Agricultural } \\
\text { income }\end{array}$ & $\begin{array}{c}\text { Land rent(exclusive } \\
\text { of }\end{array}$ \\
\hline $1910-14$ & 31.0 & 5.53 & 0.99 \\
& $(100)$ & $(17.8)$ & $(3.2)$ \\
$1955-57$ & 292.0 & 16.60 & 1.85 \\
& $(100)$ & $(5.7)$ & $(0.6)$ \\
\hline
\end{tabular}

Note : Figures inside parentheses denote percentage.

* Data from Schultz (1960).

From a different angle, these data indicate that there was not much of an increase in derivative demand for agricultural land, and that during a corresponding period the price of agricultural land declined in relation to other prices instead of going up. Moreover, the fact that agricultural production increased by about $80 \%$, despite a small decline from about $3,300,000$ acres to $3,260,000$ acres during the corresponding period suggests that in agricultural production, land and other production factors were mutually alternating.

Thus, Schultz observed, attaching less significance to land in the problems of economic growth of developed countries, that land and capital were able to substitute. Inferior land was defined as that which is hard to substitute for capital, and superior land as that which can be substituted for capital easily. Further, he maintained that, in short, the distinction between superior and inferior land was based on the imperfection of the capital market, not on the original character of the soil. 
According to Schultz's point of view, the factor indispensable to economic growth is not land, but human capital such as education and extension which can improve the quality of the production factors: such as land, labor, capital, etc. In such circumstances, with the central emphasis on demand for land, supply of land is considered to be elastic. His observation will be valid only in that the supply of land and its capacity in developed countries is very elastic along with the increase in the yield per acre because of the technological innovations in agriculture. In Japan and some other countries, supply of land is quite inelastic and, therefore, land is a production factor which cannot be disregarded.

We have heard many controversy among modern economists as to land and land rent. However, the so-called land rent comprises wage and interest in a complex fashion with no distinction between them. By naming such land rent "farmer's land rent" Ohkawa distinguished it from a pure land rent determined solely by the marginal productivity of land.

The rent which the farmers pay to the landlord for their leased land is called farmers' rent. For the most part, it includes a part of profit and wage in addition to pure land rent. Ohkawa's concept of farmer's land rent may be similar to this definition.

\section{AGRICULTURAL LAND PRICE}

\section{A. Long-run fluctuations of agricultnral land price}

Agricultural land price is expressed as $\mathrm{r} / \mathrm{m}$, where ( $\mathrm{r}$ ) is land rent and (m) is interest rate. For instance, if land rent is $\mathbf{\$ 3 0 0}$ and the interest rate is 10 $\%$, then the land price will be $\$ 300 / 0.1$ or $\$ 3,000$. However, agricultural land price is in fact influenced by various factors and would not be determined from the above theory.

Fisrt, we will look into the long-run fluctuations of agricultural land price. The survey first conducted in 1912 and onward by The Hypothec Bank of Japan provides the data for this study. In this survey, people in agricultural cooperatives, town offices and village offices who were acquainted with the price of farmland were inquired about the sale price of paddy land and upland areas. The data were collected for each prefecture.

Since 1942, a new method of survey has been carried out by well versed individuals who have known agricultural situations in each village. They were able to collect sale prices and publicize the results. This survey embodies several problems. Such individual reports of the expected price and the average sale price did not reveal regional differences within a prefecture. Since 1959 this survey has been conducted by The Japan Real Estate Research Institute instead of The Hypothec Bank of Japan.

There is another survey of agricultural land price, announced publicly after World War II. It was first started by The National Agricultural Conference in 1956. Both of these surveys revealing almost the same levels of price before 1959, have reported different levels of price since 1960. There was a rapid increase in the land price according to the survey of The National Agricultural Conference, whereas there was a slow increase according to that of The Japan 
Real Estate Research Institute (1970).

This discrepancy between the two surveys was brought on by the influence of the price of transformed land* rising since 1960. In the survey of The National Agricultural Conference agricultural land price did not identify the following two categories. One is influenced by the price of transformed land and the other not affected by it. The Japan Real Estate Research Institute estimated the pure agricultural land price by excluding the agricultural land price influenced by transformed land. By use of theses surveys, we can compare the land price between the pre-war and the post-war eras.

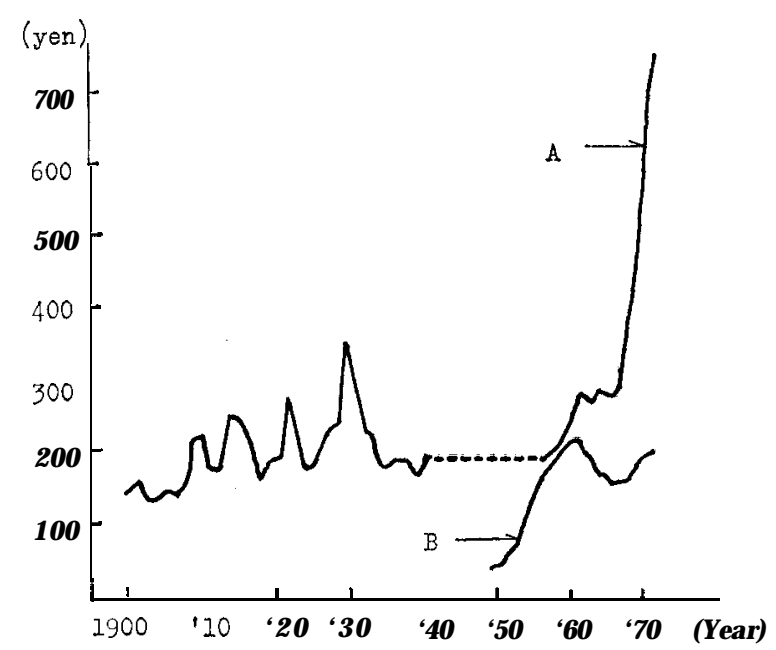

Fig. 1. Contrast between the pre-war and the post-war real agricultural land price. Note : Real agricultural land price=nominal agricultural land price/rice price index. A : The National Agricultural Conference (1970). B : The Japan Real Estate Research Institute (1970). Rice price index from Umemura et al. (1966).

Fig. 1 shows real agricultural land price which was established by dividing the nominal agricultural land price by the rice price index, based on the rice price during the years 1904-1906.

In Fig. 1 real agricultural land price for the period between 1941 and 1948 is deleted. This is due to the fact that the Agricultural Land Price Control Act, passed in 1941, regulated the agricultural land price. Therefore, the evaluation of agricultural land prices during that period provided by The Hypothec Bank of Japan do not appear on the graph.

As shown in the figure, before World War II the sharp fluctuations in the rice price reflected the fluctuations in the agricultural land prices. In this connection there was a great slump in the rice price in 1915, and to cope with this sudden fall the government passed the Rice Price Control Act. Conversely, in 1918 the consumption of rice increased and as a result of the sharp rise in price, rice riots occurred all over the country. In 1919 this high rice price resulted

* The price of agricultural land which was transformed into land for housing or industry. 
in the nominal sale price of 706 yen for average ordinary paddy land which is the highest nominal agricultural land price for the pre-war period. The real agricultural land price in 1930 was the highest for the pre-war period, due to the fact that in 1930 a splendid harvest induced a sudden fall of the rice price index down to the level of the early Taisho era.

Thus, before World War II, the real agricultural land price heavily fluctuated at a level of about 200 yen. According to the data provdied by The Japan Real Estate Research Institute, the agricultural land price sharply fell immediately after the war, and finally recovered to the pre-war level in 1958. After 1961, again, the agricultural land price fell. The great increase in rice price was provoked because of the "Method of Compensation to Production Cost and Income" which had become a new computation method of the rice price and had prevented the level of the nominal land price from matching the increasing level of rice price. After 1968, because of the fact that surplus production of rice caused the rice price to be left deferred, the nominal agricultural land price went up and consequently the real price rose.

According to the real land price estimated with the use of the data of The National Agricultural Conference, the post-war price is by far higher than the pre-war price and this may be owing to the influence of transformed land.

\section{B. Pre-war agricultural land price}

Komine (1933) conducted representative research on the pre-war agricultural land price. He submitted the following factors contributing to the rise and dip in the agricultural land prices ; (1) natural factor — the productivity of agricultural land, and (2) economic fartors -- the price of agricultural products, the moderate relation between agricultural land and the market, farm rent, local interest rate, and the purchasing power of farmers. He assessed the weight of these factors' influence on the rise and dip in the agricultural land pirce by measuring the correlation coefficient.

He measured the correlation coefficient for 1919, 1925 and 1931 by taking the value of rice production per 10 ares as productivity, the farm rent of ordinary paddy land as farm rent, the presumed amount of postal savings per head of the population of rural area as purchasing power, interest rate on the mortgages of real estate among individuals as interest rate, and acreage of paddy land per farm-household as an index representing demand for agricultural land. He came to the following conclusions: 1) During the Taisho era productivity (or the amount produced per $\mathbf{1 0}$ ares) had great influence on the undulations of the agricutulral land price. With the beginning of the Showa era the influence of productivity on farm land was gradually taken over by land rent. 2) With the depression, the relationship between purchasing power and cultivated land price became deep, but in 1931 purchasing power had the second greatest influence next to farm rent. 3) Historically the relationship between local interest and cultivated land price was closer in a depression period than in a boom period. 4) The intensity of demand for cultivated land had slight influence and its influence would become greater only if accompanied by the participation of purchasing power. 
Table 2. Correlation coefficient for price of paddy field and the amount produced per 10 ares, and farm rent.

\begin{tabular}{cccc}
\hline Year & 1919 & 1925 & 1931 \\
\hline $\begin{array}{c}\text { Price of paddy field and the amount } \\
\text { produced per 10 ares }\end{array}$ & 0.74 & 0.64 & $0.52: "$ \\
Price of paddy field and farm rent & 0.71 & 0.69 & 0.73 \\
\hline
\end{tabular}

* This data from Sakamoto (1958). Other data from Komine (19.33).

Part of the results of Komine's measurement of the correlation coefficient are shown in Table 2. The table indicates that the correlation coefficient between paddy land price and yield from paddy declined. As therefore pointed out by Komine, it appears likely that the influence of yield on the formation of paddy land price was declining during the years 1919-1931. Sakamoto (1958) already has indicated such a conclusion is problematical. The correlation coefficient for 1937 between the ordinary paddy land price for each prefecture and the yield per 10 ares, inclusive of the second crop for each prefecture, was 0.77 and hence turns out higher than those for the year 1919, 1925 and 1931. Possibly Komine's assertion that the relationship between yield and the agricultural land price weakened is not valid.

In order to look into both of their assertions, we must now estimate the correlation coefficient between the agricultural land price and productivity (or the yield per 10 ares) through adding some more years to Komine's research. The correlation coefficient for the year 1913, 1925, 1931, 1937 and 1940 are shown in Table 3. The data used here are The Japan Real Estate Research Institute's (1965), "Inquiry on Price of Paddy Field and Upland Field and Farm Rent" for the ordinary paddy land price: The Ministry of Agriculture and Forestry's (1955) "Annual Statistical Table of Farm Products," for the yield from paddy, and the average for each prefecture five of the seven years prior to the cited. (The highest and the lowest yields were not included in the average.)

Table 3. Correlation coefficient of price of ordinary paddy field and yield from paddy."

\begin{tabular}{|c|c|c|c|c|c|c|c|}
\hline Yea & & 1913 & 1919 & 1925 & 1931 & 1937 & 1940 \\
\hline Correlation & coefficient & 0.689 & 0.611 & 0.473 & 0.343 & 0.579 & 0.402 \\
\hline
\end{tabular}

Table 3 shows that the correlation coefficient which once declined during the years 1913-1931 rises again, implying that Sakamoto's criticism on Komine's findings are reasonable and that the influence of the yield of paddy per 10 ares on the formation of the agricultural land price weakened.

In addition to the previous calculation, Sakamoto calculated the multiple regression coefficient between local interest rate and the paddy land price at 0.34 for 1931 and contended that the land condition (or farm rent) and the local economic condition (or local interest rate) threw light on the formation of the paddy land price, To examine Sakamoto's study we calculate the rate of yield of ordinary paddy field per 10 ares for 1919, 1925 and 1931 with the use of Ko- 
Table 4. Rate of yield from paddy field.*

\begin{tabular}{cccrrr}
\hline $\begin{array}{c}\text { Rate } \\
\text { y1eld }\end{array}$ & $3.1-4.0$ & $4.1-6.0$ & $9.1-8.0$ & $8.1-10.0$ & $10.1-$ \\
\hline$-\quad-\quad$ & 0 & 1 & 13 & 27 & 4 \\
1919 & 0 & 9 & 35 & 1 & \\
1931 & 2 & 37 & 6 & 0 & \\
\hline
\end{tabular}

Note : Data denote the number of prefectures.

* Data from The Japan Statistical Research Institute (1958).

mine's data on the ordinary paddy field price and farm rent. As shown in Table 4 , the rate of yield for most of the years lie between 4 and 10 percent. According to the publication, "Collection of Statistics in Japan" published by The Japan Statistical Research Institute in 1958, the minimum limit of the deposit interest rate and the maximum limit of loan interest rate for the corresponding period are 4 and 10 percent, respectively. That is, the rate of yield from paddy land is between the minimum limit of the deposit interest rate and the maximum limit of the loan interest rate. We may, therefore, conclude that after the late Taisho era the agricultural land price was conditioned by farm rent.

\section{Post-war agricultural land price}

Even if we concur in the findings of the survey, land prices disregard regional economic differences because of the lack of data for the pre-war period, a more elaborate survey on the post-war agricultural land price will be necessary to incorporate the ample data available in this period. The survey carried out by The National Agricultural Conference provides us with data on the agricultural land price in the sub-divisions within each prefecture. In this survey Town and Village Agricultural Committees classified not only the price written on the application in connection with the Agriculture Land Law, but also the sale price on which the actual dealings were performed within the investigated region during the year are revealed. By this means, the actual prices are featured in this survey. Hence this survey is appropriate to see the post-war tendency of agricultural land price.

There was also research work conducted by Nakamura (1966) based on The National Agricultural Conference's data. In his research he mentioned that agricultural land dealing today was above $\mathbf{1 0}$ ares on the average and ther farmhousehold who purchased land did not require additional labor. The returns from the additional land is known as marginal revenue. If the capitalized marginal revenue is the actural sale price, it would be naturally higher than the capitalized average revenue. Theoretically, the marginal revenue should be considered in such a way within marginal revenue land price as a maximum limit and average revenue land price as a minimum limit, then agricultural land price fluctuation is influenced by the social conditions of the time.

To verify Nakamura's view the author calculated the average revenue of land from the survey for the rice production cost in Saga Prefecture. Looking upon as the actual land price the revenue land price and the sale price of average paddy land given in the research done by The National Agricultural Conference of Saga Prefecture, Fig. 2 shows a contrast between revenue land 
price and actual land price, In the figure only the findings of net revenue from land estimated by the use of interest rate of 8 percent as capital interest rate are delineated. This is simply because the results of the estimation with the use of the interest rate of 8 percent conforms with the actual land price, though net revenue from land was calculated by use of interest rates of 6 and 10 percent.

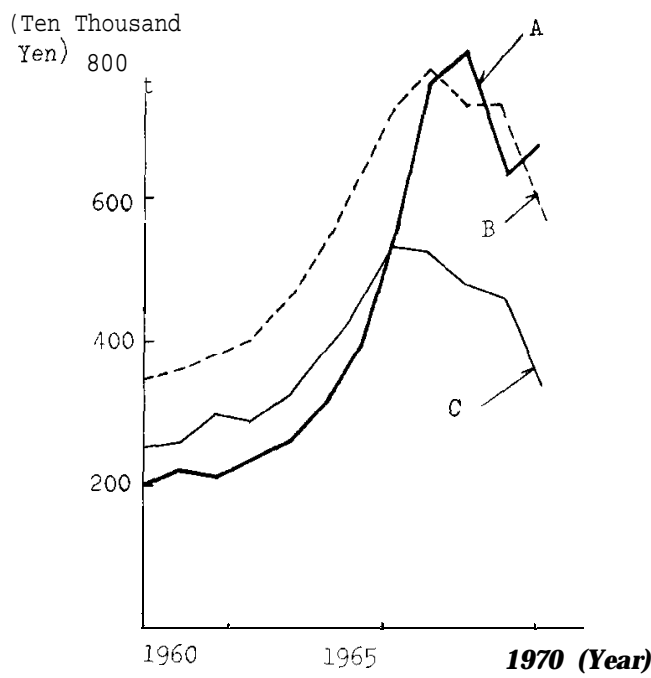

Pig. 2. Land price and net revenue of land (Saga Prefecture).

Note : Net Revenue from average land $=$ (Gross returns) - (the 1 st production cost) -(capital interest). Net Revenue from marginal land $=$ (Gross returns) - (the $1 \mathrm{st}$ production cost) - (capital interest) + (labor cost). Each revenue is capitalized by interest rate of $8 \%$, being average revenue land price and marginal revenue land price, respectively. A : Land price acquired through The National Agricultural Conference. B : Land price calculated by marginal revenue. C: Land price calculated by average revenue.

Nakamura (1966) has made previous observations that the actual land price lies between the minimum limit of capitalized value of average revenue (or the net revenue of land per 10 ares) and the maximum limit of capitalized value of marginal revenue. But his observation does not explain capitalized value of average revenue exceeds the actual land price and this is not necessarily the minimum limit of the actual price. However, on a broad survey, the actual price of agicultural land will be, to a considerable extent, in terms of average revenue and marginal revenue as calculated with the use of an 8 percent interest rate.

\section{TECHNOLOGICAL PROGRESS IN AGRICULTURE AND LAND RENT}

Let us see how technological progress in agriculture influenced the formation of land rent, on the basis of the theory of Herdt and Cochrane (1966). 
They developed their theory on the premises of 1) diffusion of technological progress in agriculture, 2) constant returns to scale, and 3) supported price of farm products. Fig. 3 illustrates the cost curves under pure competition with land $(\mathrm{T})$ remaining constant, whereas the imputs of labor $(\mathrm{L})$ and capital (K) are variable. Under the system of price support for farm products, average revenue is equal to marginal revenue since a farmer can anticipate that many farm products will sell at the same price. Assuming that a farmer operates at an equilibrium point without any surplus profit, then he may be operating at point $\mathrm{A}$ where $\mathrm{AC}$, is at a minimum.

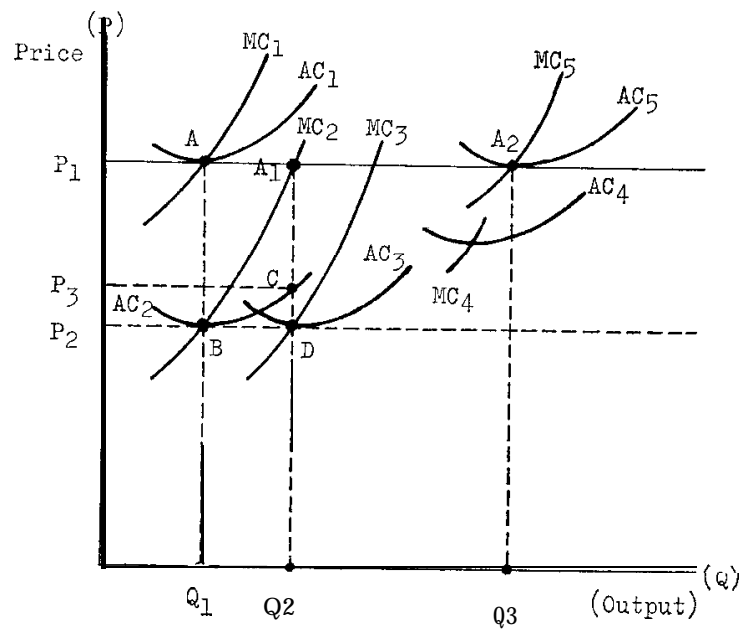

Fig. 3. Technological progress in agriculture and land rent.

Technological progress in agriculture makes it possible to extend the output while the input remains the same. Therefore, the cost for the corresponding output may well decrease and the cost curves $\mathrm{AC}$, and $\mathrm{MC}$, shift downward to $\mathrm{AC}_{2}$ and $\mathrm{MC}$, respectively. Then the farmer will profit, from the surplus $\mathrm{P}_{1} \mathrm{ABP}_{2}$. Under the present status, for maximum profit, he will increase the output up to the point $\mathrm{A}$, where marginal revenue is equal to marginal cost. At $\mathrm{A}$, where the average cost is $\mathrm{Q}_{2} \mathrm{C}=\mathrm{OP}_{3}$, and output is $\mathrm{OQ}$, surplus profit obtained by the farmer is represented by the area of the rectangle $P_{1} A_{1} C P_{3}$. Suppose the farmer enlarges his operating scale with a resulting average cost curve of $\mathrm{AC}$, (under the law of constant returns to scale). He can then maintain the output $\mathrm{OQ}$, even at the lower price $O P$, and hence he will have the surplus profit of $P_{1} A_{i} D_{2}$, which is larger than $P_{1} A_{1} C_{3}$. As a result, he will enlarge his operating scale so that the average cost curve becomes $\mathrm{AC}$. If, for the aforementioned reason, many farmers purchase land for expansion, then the land price will go up inevitably and the average cost curve will become AC, This situation develops gradually and the average cost curve will turn out to be $\mathrm{AC}$, The operation will continue until equilibrium point $\mathrm{A}$, is reached. At equilibrium, the equilibrium output is $\mathrm{OQ}_{3}$ and there would be no surplus 
profit.

In support, Chikugo Plain, a rice-producing area in Fukuoka Prefecture may be used as an example for explanation as illustrated in Fig. 4. Production cost curves for 1959 and 1968 are based on 1968 price. During the years from 1959 to 1968 , the production cost of rice per kilogram went down by approximately 22 yen (based on the price of 1968). This was done through technological progress in rice production.

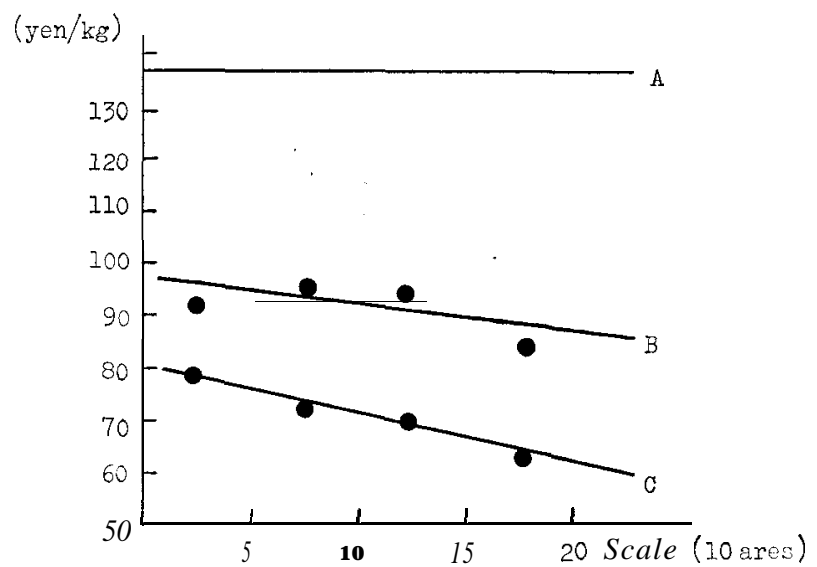

Fig. 4. Technological progress in rice Production and land rent (Chikugo Plain, Fukuoka Prefecture). Note : A : Producer's rice Price (137.7 yen/kg). B: 1959 (on the average, $93.1 \mathrm{yen} / \mathrm{kg}$ ), C : 1968 (on the average, $71.6 \mathrm{yen} / \mathrm{kg}$ ).

The padddy land (Chu Den) price increased from 211,000 yen in 1959 to 602,000 yen in 1968. But, even if we compare these two prices, differences would not be too significant because the price for 1959, if converted into the land price for 1968 by use of the producer's rice price index which doubled in the same period, would be 422,000 yen. The 180,000 yen, land price comparative difference between the two years will be, to some extent, justified by the diminished production cost resulting from technological progress in agriculture.

As already mentiond, farmers reduced their production cost by 22 yen per kilogram as a result of technological progress in rice production, and since the supported rice price remained the same, they acquired a profit of 22 yen at the end. The average yield for paddy land per 10 ares in relation to Chikugo area in 1968 is 560 kilogram. Accordingly, the profit per 10 ares is 22 yen multiply 560 kilogram or 12,320 yen. If this being capitalized with 8 percent interest rate, the increase of land price will be 154,000 yen (obtained by 12,320 yen/0.08), and it follows that this increase will be explained mostly by technological progress in rice production.

\section{REFERENCES}

Harrod, R. F. 1951 Towards a Dynamic Economics. Macmillan, London

Herdt, R. W. and W. W. Cochrane, 1966 Farm Land Price and Farm Technological Advance.

Journal of Farm Economies, 48 (2) : 243-263 
Hicks, J. R. 1954 Social Framework: An Introduction to Economics. Clarendon Press, Oxford Japan Real Estate Research Institute 1965 Tahata Kakaku oyobi Kosakuryo Shirabe (Inquiry on Price Paddy Field and Upland Field and Farm Rent). The Japan Real Estate Research Institute, Tokyo (In Japanese)

Japan Real Estate Research Institute 1970 An Inquiry on Price of Paddy Field an Upland Field, and Farm Rent. The Japan Real Estate Research Institute, Tokyo (In Japanese)

Japan Statistical Research Institute 1958 Collection of Statistics in Japan. The Japan Statistical Research Institute, Tokyo (In Japanese)

Komine, M. 1933 Nihon Kochi Kakaku no Kenkyu (Research on Arable Land Price in Japan). Koyo shoin, Tokyo (In Japanese)

Marshall, A. 1922 Principles of Economics. Macmillan, London

Ministry of Agriculture and Forestry 1.955 Nosakumotsu Ruinen Tokei (Annual Statistical Table of Farm Products). The Ministry of Agriculture and Forestry, Tokyo (In Japanese)

Nakamura, H. 3966 Nochi Kakaku no Doko (Tendency of the Agricultural Land Price). Choki Kinyu (Long-term Finance), 2 (2) : 72-80 (In Japanese)

National Agricultural Conference 1970 Findings on the Sale Price of Paddy Field and Upland Field. The National Agricultural Conference, Tokyo (In Japanese)

Ohkawa, K. 1956 Nogyo no Keizai Bunseki (Economic Analysis of Agriculture). Taimeido, Tokyo (In Japanese)

Ricardo, D. 1927 Principles of Political Economy, and Taxation, revised edition. J. M. Dent Press, London (Original, 1821)

Robinson, J. 1964 Economics of Imperfect Competition. Macmillan, London

Sakamoto, K. 1958 Tochi Kakaku Hosoku no Kenkyu (Research on Law of Land Price). Miraisha, Tokyo (In Japanese)

Schultz, T. W. 1957 Economic O rganization of Agriculture. Mc-Grow Hill Press, New York

Schultz, T. W. 1960 Land Economic Growth. In "Modern Land Policy", ed. by Land Economic Institute. Univ. of Illinois Press, Urbana

Stigler, G. A. 1968 Production and Distribution Theories, Formative Period. Macmillan, New York

Umemura, M., S. Yamada, Y. Hayami, N. Takamatsu and M. Kumazaki 1966 Noringyo (Agriculture and Forestry). Toyokeizai-shinposha, Tokyo (In Japanese)

Wickstead, P. 1894 An Essay on the Coodination of the Theory of Distribution. London (Quoted from Stigler, 1968) 